Примљено: 28.02.2021.

Прихваћено: 05.04.2021.

Владимир Карановић

Филолошки факултет, Универзитет у Београду

\title{
НАСИЉЕ НАД ЖЕНАМА И ДИСКУРС О ЖЕНСКОМ ТЕЛУ У ДРАМСКОМ ДЕЛУ ФУЕНТЕОВЕХУНА ЛОПЕА ДЕ ВЕГЕ
}

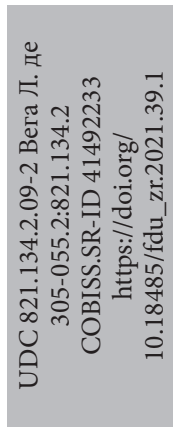

\section{Апстракт}

Полазећи од општих теоријских поставки феминистичке критике, посебно постулата који се односе на дискурс о женској телесности, у раду се разматрају маргинализована слика жене и механизми периепиије женског тела у драмском делу Фуентеовехуна Лопеа де Веге (1562-1635) у контексту специфичних образаца друштвено прихватьивог понашана и концепиије части и честитости у барокној Шпанији. Основни иитеви овог истраживата су: конкретизаиија маргинализованог положаја жене у ригидном шпанском друштву „златног доба”; указивате на процес у којем се тело, посебно женско, у драмском делу шпанског барокног писца појављује не само као предмет желье, већ и пасивни, објективизирани чувар морала, части и породичне честитости; одређивағье функиије насиьа према женама и специфичног (не)субверзивног дискурса о женском телу. Наведена анализа омогућава такше и темельние сагледаване свеукупног (анти)феминистичког идеаријума Лопеа де Веге, у чијем је драмском опусу неретко истииан наводни револуиионарни и слободарски потениијал, а истовремено занемариван утииај епохе у којој је писаи живео и стварао.

\section{Кльучне речи}

Лопе де Вега, Фуентеовехуна, шпанско позориште барока, насиље над женама, феминистичка критика

1 vladimir.karanovic@fil.bg.ac.rs 


\section{Увод}

Током седамдесетих година XX века, као последица одређених постструктуралистичких учења, настаје и развија се један нови облик посматрања, анализе и критике књижевног текста, с циљем да се књижевна дела читају и тумаче у складу с „родним” критеријумима, али и да се прошири теоријски корпус феминистичких истраживања у оквирима студија културе (Gómez Redondo 2008: 407). Познато је да феминистичка критика, у најширем смислу, подразумева неку врсту употребе књижевног или неког другог уметничког дела у светлу женског искуства. У области књижевне анализе говоримо о приступу тексту у којем се анализира не само визија света из угла женског искуства и слике жене, већ и из перспективе полних разлика показаних у неком књижевном делу (Bužinjska \& Markovski 2009: 436-437). У овом контексту можда још већи значај има појава тзв. ревизионистичке феминистичке критике, која је углавном била усмерена на истраживања мизогиних мотива у књижевности, али и на анализу репресивних елемената према женама, женског питања и откривања доминантног патријархалног дискурса и стереотипа у појавним облицима жене у друштву и култури. Тако нпр. Лис Иригаре (Luce Irigaray) у делу Speculum другог: жена (Spéculum de l'autre femme, 1974) покреће низ ревизионистичких постулата у односу на феминистички дискурс заступљен у постструктуралистичким учењима. Залагала се за одбацивање фројдовског и лакановског фалоцентричног дискурса о жени и једностране перспективе коју су имале њене мушке колеге, као традиционални „господари дискурса”. Настојала је да створи нови дискурс, који ће разматрати оно „женски имагинарно” и „женски симболичко", уз све пропратне структуре које одговарају морфологији женског тела (Lešić 2006: 446). Такође, подржавала је развој концепције „другости” жене у смислу женске сексуалности, сматрајући да једино истицање женске различитости у овом контексту - пре свега њене флуидности и вишеструкости појавних форми - може прекинути спиралу погрешних представа које о њој доминирају западном цивилизацијом (Selden et al. 1997: 145). Битан проблемски блок ове врсте преиспитивања женског принципа, специфичне природе и диференцијације жене јесте и питање тела и телесности, чији се значај у садржинском смислу мења кроз историју, премда је женска телесност увек будила пажњу и заузимала важно место у студијама културе. Тако и Јелена Ђорђевић (2009: 162) истиче да је тело „једна од културних чињеница од прворазредног значаја за свако разумевање друштва и културе”. Управо је широко поље савремене феминистичке критике усредсређено на пи- 
тање женског тела и телесности, а студије културе пажњу посвећују проучавању тела као тачке у којој се одвија сукоб, пружа отпор, збива подређивање, оспоравање, доминација или било који облик хегемоније (Đorđević 2009: 171).

\section{Перцепција жене и објективизација женског тела у шпанском друштву „златног доба”2}

Док је у средњем веку тело посматрано у контексту разлике у односу на душу, као израз нечег грешног, исквареног, мање вредног, посебно је женско тело морало бити контролисано и под сталним надзором како жена не би уживала или истицала своје биолошке специфичности и могућности. Чини се да ће XVII век такође развити овакав поглед на жену и њену телесност, а женско тело ће се сматрати опасним, изазовним резервоаром греха, док ће се инсистирати на развоју механизама контроле како би се жена саобразила потребама патријархалног друштва и оновременим идеолошким системима усмереним ка понављању истог и одржању традиције. Стога се женско тело разматра у контексту кодификованог објекта, у складу с друштвено-културолошким приликама, чије се идеје заснивају на библијској традицији и филозофији, а о свеколиком концепту телесности и о идејном систему мора бринути мушкарац, стуб патријархалног устројства (Sánchez Dueñas 2008: 283). Дакле, упркос томе што је женско тело у основи део сфере приватности и личног, репресија патријархалног система и идеологија нужне мушке доминације над женама учинили су могућим да у европским, па и у шпанском друштву, мушкарац наметне доминантан дискурс о женској телесности, у чијим основама су ограничења, забране и низ казни за непоштовање утврђеног система, будући да је свако одступање од норме у овој области подразумевало извесну опасност за целокупан друштвени систем.

Маргинализован положај и статус латентне жртве насиља које жена има у шпанском друштву „златног доба” заправо су резултат парадоксално

2 Појам „златно доба" (Siglo de oro, Siglos de oro, Edad de oro) мења значење кроз историју, а у новије време хиспанисти настоје да јасно поставе његове границе и прецизније објасне значење. У најширем смислу, почетком овог периода сматра се 1492. година, вишеструко значајна за хиспански свет, док се завршетком сматра 1681. година, када умире Педро Калдерон де ла Барка и завршава се барок у шпанској књижевности. Реч је о периоду шпанске доминације у историјском и политичком смислу, али и плодне уметничке активности, коју су обележили универзални симболи националне и светске културне баштине. 
високог положаја и значаја који је имала у друштвеном систему и у питањима породичне части (Rodríguez-San Pedro Bezares \& Sánchez Lora 2000: 242). Зато тема части (honor/honra) ${ }^{3}$ и њени различити појавни облици имају изузетан значај у контексту анализе насиља према женама, али и контроле, поседовања и општег дискурса о женском телу у корпусу шпанске барокне драме. У складу с преовлађујућом перцепцијом епохе, част (el honor) је морална категорија, углавном својина племства, наслеђивала се и стицала рођењем у вишим друштвеним слојевима, краљевским одлукама, значајним богатством или изузетним заслугама. С друге стране, част, тј. честитост (la honra) подразумева вредновање и поштовање сопственог достојанства и зависи од перцепције других, доброг реномеа или од врлина и честитости појединца, по правилу жене (Penas Ibáñez 2004: 52-53). Тако част (honra) вреди више од живота, а бешчашће (deshonra) је горе од смрти, постаје вечна категорија, која се преноси и на потомке. Услед оваквог вредновања части и честитости јасно је зашто се у моралном и социјалном кодексу оправдава смрт онога ко је другом одузео част. Једини начин да се увреда части надокнади јесте да мушкарац ожени женску особу коју је искористио, или пак да физички нестане, чиме се поништава увреда јер је смрт симболична надокнада за почињено недело (MacGrady 2001: 132).

У оквиру драмског кодекса части Шпаније „златног доба”, уколико посматрамо сегмент мушко-женских односа у хронолошком животном следу, кћер „припада” оцу, брату, а потом супругу. Овај облик припадања мушкарцу жену поништава као независно и слободно биће, сводећи је на продужетак части мушкарца и референтне породице (Díez Borque 1976: 87-88). Стога отац или други мушки члан породице морају повратити евентуални губитак части (морално посрнуће жене, напад на телесну чистоту и чедност жене) као да се ради о њима самима, о личној одбрани мушког поноса и части, док су жена и њено тело објективизовани, дехуманизовани и деиндивидуализовани. Кодекс части тога времена подразумевао је да сваки облик њеног нарушавања захтева хитно делање. Оно је могло значити јавну или тајну освету, у односу на то да ли је увреда била јавна или се догодила у тајности. Такође, само је чин новог насиља, у којем обешчашћени мушкарац пролива крв изгредника, значио ваљани повратак у окриље шире заједнице и поновно успостављање система, а валоризацију тог процеса спроводили су други чланови друштва (Gil Ambrona 2008: 326).

3 Варијанте ове речи на шпанском, у зависности од рода именице, имају различита специфична значења која би требало увек узимати у обзир. 


\section{Фуентеовехуна: драма о честитости и(ли) драма о инструментализованом насиљу над женама?}

Лопе де Вега (Lope Félix de Vega у Carpio, 1562-1635) један је од најпознатијих шпанских драмских писаца свих времена и аутор преко 400 драмских комада. Био је централна фигура шпанског позоришта „златног доба" и творац хибридне врсте: нове или шпанске комедије (comedia nueva o española $)^{4}$. Према речима Јасне Стојановић (2009: 40), „својим талентом и изванредним драмским осећајем дао је формулу нове комедије и неизбрисив печат целокупном позоришном животу тог доба". Драмски опус Лопеа де Веге заснива се на четири најважнија тематска оквира: монархистичко уређење, верска правоверност, одбрана части и љубав (Penas Ibáñez 2004: 51). Тема части има неспорни значај у његовом драмском систему, чега је писац био свестан, претварајући је, према речима Хуана Луиса Алборга (Alborg Juan Luis Alborg), у један од најмоћнијих покретача нове комедије (Alborg 1999: 282). Не треба заборавити да Лопе у својој поетици под насловом Ново умеће писаға комедија (Arte пиеvo de hacer comedias 1609), наводећи пожељне тематске оквире шпанске хибридне драмске врсте, истиче управо тему части: "Los casos de la honra son mejores / porque mueven con fuerza a toda gente, / con ellos las acciones virtuosas, / que la virtud es dondequiera amada"5 (Vega 2006: 149).

Нова или шпанска комедија садржи велики број ликова који припадају различитим друштвеним слојевима, али и оригиналне драмске обрасце класичног шпанског театра. Посреди су схематизовани, ретко продубљени ликови, а њихова функција на сцени, конвенција делања

4 Нова или шпанска комедија је назив за специфичну драмску врсту насталу у Шпанији последњих година XVI, а развијену у првим деценијама XVII века. Њеним творцем сматра се Лопе де Вега. Ова драмска врста одступа од традиционалних врста античког и ренесансног театра будући да садржи трагичне и комичне елементе (стога је и најближа трагикомедији), ликове из различитих друштвених слојева, састоји се од три чина (уместо некадашњих пет или четири, у зависности од периода развоја драме), писана је искључиво у стиху, углавном с циљем да забави публику и допринесе популаризацији оновременог националног театра. Ликови су типски (дама, удварач, моћник, краљ, отац, слуга, шаљивџија итд.), језик је природан и разумљив ширем кругу гледалаца, а чувена три драмска јединства су нарушена, те је приступ драмских писаца структурној организацији дела био посве флексибилан. Теме су углавном историјске, митолошке, социјалне, љубавне, а популарност овакве врсте драме превазилазила је националне оквире, те данас нова или шпанска комедија чини важно поглавље у историји светске драме.

5 „Најбоља је згода када је о части / јер силно узбуди сваког и покрене, / поред ње су одмах племенита дела, / јер врлину вазда и посвуда цене" (превод Владимир Карановић, препев Жељко Донић, Вега 2013: 44). 
и драмски потенцијал, могли су варирати у складу са ситуацијом или потребама драмске радње. Ипак, један од одлучујућих фактора устројства ликова била је идеолошка основа дела и порука коју драмски писац жели да пренесе гледаоцима. Иако се у новој комедији јављају типски ликови - дама, госпа (la dama), удварач, каваљер (el galán), шаљивџија (el gracioso), краљ (el rey), отац (el padre) - у делима с темама из националне историје долази до мање промене у саставу ликова, улогу главног, заљубљеног пара имају сељак и сељанка (villano, villana, labrador, labradora), а њихову љубав осујећује моћник (el poderoso) (Stojanović 2009: 47-48). Лик даме или сељанке посебно је значајан за анализу мотива части, будући да одражава специфичну идеологију драмског писца, а у неким случајевима и потенцијал (анти)феминистичког идеаријума аутора нове комедије.

Драмско дело Фуентеовехуна (Fuente Ovejuna, 1612-1614, објављено 1619. године) припада групи дела с тематиком из националне историје, а настаје у најплоднијој фази стваралаштва аутора (1604-1618). Одабрани догађај историјског карактера преузет је из шпанских хроника, али је највећи део радње фиктивне природе: побуна становника варошице Фуентеовехуна против намесника Фернана Гомес де Гусмана (Fernán Gómez de Guzmán), који злоставља поданике и локално становништво, а посебно искоришћава и напаствује жене. Након бројних недела које је починио, намесник изазива бес међу становницима варошице, који устају против свог господара и убијају га. По спроведеној истрази и услед немогућности да се издвоји индивидуални кривац за почињено убиство, краљевски пар (Изабела и Фернандо, познатији као „Католички краљевски пар” - Los Reyes Católicos) опрашта становницима Фуентеовехуне.

У овом драмском делу насиље је присутно на неколико нивоа, спроводи га углавном намесник Фернан Гомес, а насиље као одговор на дуготрајно злостављање спроводиће народ у последњој трећини драме. Очигледна је градација у приказивању насиља које спроводи намесник, а осим према женама, бес и насиље усмерава према сељацима, ниподаштавајући њихово достојанство и ругајући се њиховој концепцији части (Stojanović 2009: 59). Сексуални апетит намесника појављује се као мотив од почетка драме, а биће повод за каснију побуну народа и трагичну смрт онога ко се огрешио о принципе доброг владања и поштовања поданика (Matas 1981: 385). Степен озбиљности сексуалних злочина које чини намесник има прогресивну путању, од завођења и вербалне самопромоције, задиркивања и узнемиравања, до тешког сек- 
суалног напада, а жртве су жене различитих моралних карактеристика. Његови помоћници и саучесници у злочину, Флорес (Flores) и Ортуњо (Ortuño), појачавају ефекат мушке доминације и капацитет за насиље над женама и озбиљна су претња женском телесном интегритету (Parker Aronson 2015: 35).

Bећ у почетним сценама драме примећујемо две антагонистичке перцепције моћи и доминације Фернана Гомеса и утицаја који остварује међу женама. Док у I чину Лауренсија ${ }^{6}$ (Laurencia) храбро иступа против сваког облика могуће злоупотребе овлашћења, доброг владања и поштовања морала и закона, Паскуала (Pascuala) сматра да је немогуће одупрети се његовом утицају. Овај уводни сегмент драме послужио је Лопеу као антиципација низа догађаја и епизода у којима је протагониста намесник, а предмет пожуде женски свет Фуентеовехуне. Међутим, гледалац добија и важне информације о карактерном склопу и светоназорима Лауренсије, чија ће улога бити одлучујућа за развој радње, јер пркос и одлучност у њеном одговору саговорници на негативно-фаталистички приступ у одбијању мушке пожуде има за циљ да јасно одреди моралну вертикалу овог женског лика:

Pascuala: Tendré yo por maravilla que te escapes de su mano.

Laurencia: Pues en vano es lo que ves, porque ha que me sigue un mes, y todo, Pascuala, en vano. Aquel Flores, su alcahuete, y Ortuño, aquel socarrón, me mostraron un jubón, una sarta y un copete; dixéronme tantas cosas de Fernando, su señor, que me pusieron temor; mas no serán poderosas para contrastar mi pecho. ${ }^{7}$ (Vega 2001: 91-92)

6 Узимајући у обзир чињеницу да је постојећи превод дела Фуентеовехуна на српски језик, који је средином XX века сачинио Драгослав Илић, умногоме анахрон, транскрипција оригиналних шпанских имена из дела у тексту рада начињена је у складу с позитивном праксом коју хиспанисти већ деценијама поштују у српској културној, научној и академској средини.

7 Пасквала: Богме право чудо то је / не паднеш ли њему шака. // Лавренција: Чудо ил' не, ја сам јака; / неће успет, извесно је. / Већ месец ме дана слеће / па кад залуд би му све то, 
Тако се на симболичком нивоу моћ намесника судбински повезује са становницима варошице, конфликт се јасно обзнањује, а исход настаје у складу с визијом Лауренсије, тј. с њеном идеологијом отпора (Ruiz Ramón 2000: 158).

У процесу анализе мотива насиља према жени и телесног поседовања треба се осврнути на последњу сцену I чина драме, у којој на шумском пропланку разговарају Лауренсија и Фрондосо (Frondozo). У идиличном амбијенту младић изјављује љубав драгој, али ће идеализовани тренутак и хармонију прекинути долазак Фернана Гомеса, који се након покушаја да на силу поседује Лауренсију, сукобљава с Фрондосом, чија појава из скровишта и претња украденим оружјем осујећују намеру насилника да оствари нечасни план (Карановић 2008: 110). Ова кратка сцена саткана је од симболике и сублимираних слика, а намесник има функцију и улогу „ловца на срндаћа” премда наилази на „лане”, користи арбалету, врсту самострела, као симболични фалус, средство моћи, телесне доминације и јасне предности за онога у чијим рукама се налази. Будући да је коначно насамо с Лауренсијом, која је раније пружала отпор његовим предлозима да му се преда и препусти телесном уживању, не видевши Фрондоса скривеног у жбуњу, намесник покушава да савлада девојку и загосподари њеним телом:

Comendador: ¡Qué estilo tan enfadoso! Pongo la ballesta en tierra, y a la prática de manos reduzgo melindres.

Laurencia: ¿Esso hazéis? ¿Estáis en vos? [...]

Comendador: [Sin percatarse de la salida de Frondoso.] No te defiendas. [...]

Comendador: Acaba, ríndete.

Laurencia: ¡Cielos, ayudadme agora! ${ }^{8}$ (Vega 2001: 120-121)

/ дође Флорес, оно псето, / и Ортуњо, људско смеће, / да ми нуде посластице, / златан ђердан око врата, / и хаљину од броката, / скупоцене укоснице. / Кад их одбих, они тада / господарем прете својим, / да већ почех да се бојим... (превод Драгослав Илић, Vega 1964: 12-13).

8 Командор: Да одвратних речи твојих! / Оставићу арбалету / и рукама својим, силом, / укротићу твоје ћуди. // Лавренција: Како! Јесте л’ полудели? / Шта чините? [...] Командор: Не брани се... [...] Командор: Де, предај се! Није страшно... // Лавренција: Помози ми, боже свети! (превод Драгослав Илић, Vega 1964: 38-39). 
Овај тренутак у драмској радњи последњи је у низу припремних елемената у трочланом односу намесник-Лауренсија-Фрондосо, који ће довести до ескалације насиља према девојци, њеном телу и части у сцени прекинутог венчања.

Хасинта (Jacinta) је лик који се епизодно појављује у драми, али такође завређује пажњу при анализи и проблематизацији насиља над женама. Будући да одбија намесникова удварања и покушава да сачува честитост и телесни интегритет, жртва је бруталне и деструктивне мушке сексуалности, а искоришћавање њеног тела од стране намесникових људи у функцији је најаве драстичнијих поступака и служи да припреми сцену за Лауренсијину отмицу и трагично насиље које ће претрпети. Фернан Гомес се према Хасинти опходи као према објекту који служи за разоноду, а њено тело доживљава као пуко средство да се војници групно забаве током једног од својих војних похода:

Comendador: Las pesadumbres

y el villano atrevimiento

no tiemplan bien un airado.

¡Tira por ahí!

Jacinta: ¿Con quién?

Comendador: Conmigo.

Jacinta: $\quad$ Míralo bien.

Comendador: Para tu mal lo he mirado.

Ya no mía, del bagaje

del exército has de ser.

Jacinta: $\quad$ No tiene el mundo poder

para hacerme, viva, ultraje.

Comendador: Ea, villana, camina.

Jacinta: ¡Piedad, señor!

Comendador: No hay piedad.

Jacinta:

Apelo a tu crueldad

a la justicia divina. ${ }^{9}$ (Vega 2001: 140)

9 Командор: Та кукњава тако проста / и те претње непрестане, / мислиш, то ће да ме гане? / Пођи! // Хасинта: Куда? // Командор: Са мном. Доста! // Хасинта: Размисли се! // Командор: Шта ту има! / Нећеш мене забављати, / већ ћеш своју младост дати / уз пут мојим војницима. // Хасинта: Преживети никад нећу / ту срамоту, проклетниче! // Командор: То се мене слабо тиче. / Хајд, полази! Моји крећу. // Хасинта: Милост! Милост! // Командор: Ни помена! // Хасинта: Молићу се богу горе / да те казни за покоре / казном мука и пламена! (превод Драгослав Илић, Vega 1964: 62-63). 
Након сцене II чина у којој покушава да побегне од насилника, а батине добија шаљивџија Менго (Mengo) јер једини стаје у њену одбрану супротстављајући се намесниковим људима, Хасинта се поново појављује тек у III чину, као део организоване групе жена која креће у поход на намесничку резиденцију како би се осветила за учињена злодела. Тако Хасинта од рањиве жртве у првом делу драме постаје осветница, у пуном сјају и ефектно приказана у сценама колективне побуне (Parker Aronson 2015: 38-39).

Врхунац насиља и доминације над женским телом као објектом у драми наступа на крају II чина, у сцени венчања Лауренсије и Фрондоса, коју прекида Фернан Гомес, наређује Фрондосово затварање, одводи Лауренсију у резиденцију, а њеног оца, кмета Естебана (Esteban), понижава ударцима кметским штапом, иначе симболом моћи и друштвеног престижа у нормалним околностима. Мештани остају запањени, а први тренуци одвијања кризног збора на којем се расправља о даљим корацима осликавају стање очигледне немоћи, инертности и одсуства храбрости да се кроз конкретне кораке ситуација промени.

У драмском смислу, ефектно и умешно је уклопљено излагање Лауренсије у најдраматичнијем тренутку развоја радње, на почетку III чина. Лауренсија, девојка обећана Фрондосу, кћи Естебана, племенита и поштена, доспела је у руке насилника који својим поступцима угрожава њу, али и сва повезана лица из њеног породичног и приватног окружења (Карановић 2008: 111). Када се побегавши из намесничке резиденције појави на кризном састанку мештана, коначно пали фитиљ повређене части и достојанства. Већ приликом уласка наговештава се драма, с обзиром на то да Лауренсија најављује да ће „узети реч” и да ће је сви окупљени „добро чути", чиме се преиспитује и модификује оновремени образац понашања жене у јавности:

Laurencia: Dexadme entrar, que bien puedo, en consejo de los hombres; que bien puede una mujer, si no a dar voto, a dar vozes. ¿Conocéisme? [...]

Esteban: ¡Hija mía!

Laurencia: No me nombres tu hija. 
Esteban: ¿¿Por qué, mis ojos?

¿Por qué? ${ }^{10}$ (Vega 2001: 157-158)

На неки начин овим чином, а затим и изреченим у наставку сцене, Лауренсија напушта и класичан образац формирања женског лика, она се маскулинизује и постаје хероина, заштитница жена, потлачених, маргинализованих, али и бранитељка ригидног друштвеног система и концепције части, у чијем поновном успостављању ће лично учествовати. Чувени Лауренсијин монолог индикативан је из више разлога, а посебно треба истаћи његов значај за исход драмске радње. Тенденциозан је одабир речи, али и вређање, понижавање мушких чланова заједнице, оптуживање за одсуство мушких карактеристика код оних који би требало да брину о добробити заједнице, моралу, правоверности и очувању части:

\author{
Laurencia: ¡Por muchas razones! \\ Y sean las principales, \\ porque dexas que me roben \\ tiranos sin que me vengues, \\ traidores sin que me cobres. \\ Aún no era yo de Frondoso, \\ para que digas que tome, \\ como marido, venganza, \\ que aquí por tu cuenta corre; \\ que en tanto que de las bodas \\ no haya llegado la noche, \\ del padre, y no del marido, \\ la obligación presupone; \\ que en tanto que no me entregan \\ una joya, aunque la compre, \\ no ha de correr por mi cuenta \\ las guardas ni los ladrones. \\ Llevóme de vuestros ojos \\ a su casa Fernán Gómez; \\ la oveja al lobo dexáis, \\ como cobardes pastores. [...]
}

10 Лавренција: Дозволите жени сада / да у савет људи ступи; / мада није допуштено / да глас свој да̂, ипак треба / да се бар њен вапај чује. / Знате ли ме? [...] Естебан: Кћери моја! // Лавренција: Не зови ме / ћерком својом! // Естебан: Зашто, душо? / Што? (превод Драгослав Илић, Vega 1964: 85). 
Mis cabellos, ¿no lo dizen? ¿No se ven aquí los golpes, de la sangre, y las señales? [...]

Ovejas sois, bien lo dize de Fuente Ovejuna el nombre. [...]

Liebres cobardes nacistes; bárbaros sois, no españoles. ¡Gallinas! ¡Vuestras mujeres sufrís que otros hombres gozen! ¡Poneos ruecas en la cinta! ¿Para qué os ceñís estoques? ¡Vive Dios, que he de trazar que solas mujeres cobren la honra destos tiranos, la sangre destos traidores! $¡ Y$ que os han de tirar piedras, hilanderas, maricones, amujerados, cobardes! ¡Y que mañana os adornen nuestras tocas y basquiñas, solimanes y colores! ${ }^{11}$ (Vega 2001: 158-160)

Лопе де Вега је добро познавао менталитет шпанског народа, трудећи се да подилази укусу публике и омогући јој да се лакше поистовети с догађајима на сцени (Rodríguez Cacho 2009: 400). У том смислу, не треба да изненађује намера драмског писца нити ефекат који Лауренсијине речи изазивају у даљем току радње: енергична жена, која у овој при-

11 Лавренција: Разлога има много, / а од свију најглавнији / што допусти да ме отму / тиранима без освете. / Једним прстом мако ниси / кад ме вукле издајице. / Ја још не бех Фрондозова / да си мого мирно рећи / да је дужан, ко муж, мене / он једини да освети. / Ти на његов рачун ниси / смео тако трговати, / јер ја нисам после свадбе / ни ноћ прву с њим провела, / те би дужност тебе, оца, / а не мужа, да ме брани. / Кад ниси имао снаге, / требало је најмит стражу / да адиђар непродани / од лопова боље чува. / На ваше ме води очи / својој кући Фернан Гомес: / овчицу сте вуку дали / ко пастири преплашени. [...] Моје косе не кажу л' вам? / И трагови удараца? / Погледајте и крв ову! / [...] Овце ви сте! С правом име / овом нашем селу даше. / Да, Фуенте Овехуна / кладенац је овчји само! [...] Зечеви сте ви плашљиви / од рођења и дивљаци, / а никако Шпанци нисте! / Допуштате да вам кћери / и супруге узимају / и блуд с њима да проводе! / Преслица је за вас женска! / Шта ће тај мач о појасу? / Кунем вам се, жене саме / част умеће опрат своју / крвљу оног тиранина / и његових слугерања. / А вас ћемо каменоват, / пресличарке, торокуше, / бабетине и плашљивце; / сутра ћемо навући вам / наше сукње, конђе наше, / дати траке и белило / да се женски уградите. (превод Драгослав Илић, Vega 1964: 86-87). 
лици одступа од утврђених норми понашања, има задатак да „пробуди духове”, да освести мештане, подстакне их на акцију, одбрану части и задовољење правде. Лик Лауренсије део је фиктивног вида овог драмског дела и Лопе га обликује с циљем да се појача драмски интензитет и да се публика поистовети с чином „страдања” и начињене увреде, али и да се у потпуности дехуманизује намесник, симбол зла и друштвене неправде. Према речима Франсиска Лопеса Естраде (Francisco López Estrada), драмски потенцијал овог женског лика заправо је надградња чији је творац Лопе де Вега, а конкретизација кроз тему части и огрешења о друштвене законе посебан је и вешто уклопљен елемент дела Фуентеовехуна (López Estrada 1996: 32). Једно од важних питања у развоју лика Лауренсије јесте дилема да ли је девојка силована или не, тј. да ли је њена честитост нарушена и у конкретном, експлицитном, путеном смислу. Стога је на публици да по физичком изгледу и сценској поставци лика донесе закључак, будући да драмски текст, недовољно прецизан, оставља простор за различита тумачења. У овом погледу важан је Лауренсијин физички изглед у сцени одвијања кризног састанка мештана, на којем публика може да учитава неизговорено, али и тумачи визуелне ефекте и семиотичке сигнале, попут разбарушене и откривене женске косе (Parker Aronson 2015: 37). Наиме, стандарди и морални кодекси у Шпанији тога доба подразумевали су низ препорука за одевање и „пристојно” понашање девојака у јавности, а симболика коју неуредна и откривена коса имају у овој сцени, иду у прилог тези да се обешчашћење догодило и у путеном смислу.

Коначно, од великог је значаја и сцена ислеђивања након убиства намесника, а занимљив је одабир категорија становништва које се саслушавају методама телесног кажњавања: старац, дете, жена и шаљивџија; дакле, посреди је стереотипни избор најслабијих и најосетљивијих категорија становништва (Ruiz Ramón 2000: 159). Сцена испитивања и физичког мучења је кратка и ефектна; одиграва се изван видокруга публике, иза сцене, има за циљ да подстакне машту и појача могућност идентификације гледалаца с телесним мукама ислеђиваних. Међутим, чини се да Лопе није намеравао да код публике изазове ужас колико дивљење према туђем претрпљеном физичком болу, а утисак ће потенцијално оснажити реакције Лауренсије и Фрондоса, који прислушкујући преносе окупљенима догађаје из просторије у којој се одвија мучење (Ruiz Ramón 1991: 70). Упркос мукама и претњама, сви су јединствени у одговору да је убица колективни, цела варош Фуентеовехуна. Ова врста колективитета и народног јединства, осим у конкретном случају подно- 
шења телесних мука ради виших циљева, појављује се и у питањима одбране части, као само једног сегмента обимнијег идеолошког блока који се у овој драми афирмише. У делу Фуентеовехуна част је представљена као баштина у чијем стварању учествују сви појединци, без обзира на социјално наслеђе или статус (Matas 1981: 390). Реч је о демократској тековини и основи постојећег уређења и традиције, те не изненађује одбрана тезе о оправданости народа да се бори за њено очување.

За Лауренсију и Хасинту, родна идентификација и преузимање улоге силоване жене није подразумевало пасивну улогу, те Лопе де Вега користи прилику да на примереним и важним местима драмске радње прикаже насиље над њиховим телима тако да други ликови драме, али и публика која гледа представу, несметано и непосредно уоче елементе телесног насиља над њима. Чини се да су наведени женски ликови својим делањем створили јаз између одређене концепције рода, „прихватљивог” понашања и друштвене улоге која им је намењена, с једне, и практичног и активног спровођења потребних радњи, с друге стране. Зато треба истаћи и њихову смелу и посве субверзивну идеју да врлина није условљена нити ограничена чедношћу жене, те да може опстати и постојати независно од концепције телесне чедности. У ригидном шпанском друштву референтне епохе, у којем су жене под знатним притиском и у сталној опасности да буду силоване, сексуално напаствоване или на други начин искоришћене, ризик се повећава и због њиховог родног статуса, али и због друштвено незавидног положаја и раслојавања с обзиром на то да је реч о женама из сеоске средине. Тако једини излаз из постојећег стања јесте осмишљавање стратегије која би спречила или превазишла неизбежан губитак физичке врлине и надокнадила га моралном врлином (Parker Aronson 2015: 45).

\section{Закључак}

Револуционарна димензија драме Фуентеовехуна у многим приликама је анализирана и истицана као важан вид дела и основа формирања одређених сегмената драмске радње и њеног расплета (Arellano 2005: 191). Иако се у новије време углавном одбацује тај смер интерпретације, не треба ни занемарити шири контекст у којем настаје ово дело, а посебно фактор публике у позоришним двориштима (corrales de comedias) оновремене Шпаније. На том трагу треба посматрати и бројне сцене насиља, које су у драмском смислу вешто представљене, а извесно је да 
Лопе де Вега класификује и вреднује насиље у складу са ситуацијом и степеном оправданости насилног чина: од пресудног значаја је узрок због којег се насиље спроводи, с обзиром на то да осионост, саможивост и гордост намесника појачавају негативни ефекат присуства овог мотива у формирању лика. С друге стране, насиље које настаје као одговор мештана Фуентеовехуне на злоупотребу власти и огрешење о друштвене и политичке норме шпанске монархије, имају далеко веће симпатије Лопеа де Веге, а посебно „јединство у злочину” и афирмација народа као симболичне јединке или тела, чији се делови не могу одвојити и које не мари за физичку тортуру пошто је злочин резултат „правичног делања”. Исти статус има и насиље над женама, али не услед развијене свести писца о неприхватљивости таквог чина или због присуства одређеног степена предфеминистичке идеологије, већ због значаја које женско тело, као пасивни објекат, храм породичне части/честитости, има у шпанском друштву онога времена.

Уколико ово драмско дело посматрамо у контексту пропаганде и специфичног социјалног и идеолошког хоризонта писца, потребно је преиспитати и степен демократичности Лопеа де Веге у представљању женске слободе, њеног положаја и функције коју заузима у шпанском друштву XVII века. Намеће се питање: у којој мери Лопе заступа (анти) феминистичке ставове у делу Фуентеовехуна и које механизме користи како би контекстуализовао насиље над женама у драми и с којим далекосежним циљевима? Извесно је да су женски ликови осмишљени да прикажу одређене поставке које немају за циљ да се анализира и преиспитује постојећи поредак, да се незавидна позиција шпанске жене тога доба, њена пасивна улога и телесна објективизација промене или сагледају критички како би се направили темељи једног новог друштвеног система, насталог на здравим основама, уз све специфичности разнородних елемената који чине одређену заједницу. Уместо тога, сведочимо ригидном представљању жене, женског морала, разумевању части и честитости на основу једностране и традиционалистичке перспективе, која не дозвољава дијалог или компромис. Иако у одређеним фрагментима драмског текста проналазимо елементе могуће субверзије и благе ревалоризације утврђених образаца (посебно у случајевима маскулинизације женских ликова, чије се карактеристике тиме привремено измештају из сфере феминитета), слика о привидној демократичности или слободарско-феминистичком представљању женских ликова, женског принципа и женске природе увек ће бити условљена исходом драмске радње и идеолошким системом 
који је драмски писац промовисао рачунајући на одобравање и подршку најширег круга гледалаца.

\section{Литература}

- Alborg, Juan Luis (1999) Historia de la literatura española (Vol. II - Época barroca), segunda edición con índice de nombres y obras, $7^{\text {a }}$ reimpresión. Madrid: Gredos.

- Arellano, Ignacio (2005) Historia del teatro español del siglo XVII, $3^{a}$ edición. Madrid: Ediciones Cátedra.

- Bužinjska, Ana \& Markovski, Mihal Pavel (2009) Književne teorije XX veka, s poljskog prevela Ivana Đokić-Saunderson. Beograd: Službeni glasnik.

- Vega, Lope de (1964) Fuente Ovehuna, preveo Dragoslav Ilić. Beograd: Izdavačko preduzeće „Rad”.

- Vega, Lope de (2001) Fuente Ovejuna, edición de Juan María Marín, vigésima edición. Madrid: Ediciones Cátedra.

- Vega, Lope de (2006) Arte nuevo de hacer comedias, edición de Enrique García Santo-Tomás. Madrid: Ediciones Cátedra.

- Вега, Лопе де (2013) Ново умеће писаюа комедија у ово време, превод са шпанског, белешке и поговор Владимир Карановић, стихове препевао Жељко Донић, предговор Јасна Стојановић. Београд: Партенон.

- Gil Ambrona, Antonio (2008) Historia de la violencia contra las mujeres - Misoginia y conflicto matrimonial en España. Madrid: Ediciones Cátedra.

- Gómez Redondo, Fernando (2008) Manual de Crítica Literaria contemporánea. Madrid: Editorial Castalia.

- Díez Borque, José María (1976) Sociología de la comedia española del siglo XVII. Madrid: Ediciones Cátedra.

- Đorđević, Jelena (2009) Postkultura (Uvod u studije kulture). Beograd: Clio.

- Карановић, Владимир (2008) „Документарно и фикционално у драмском делу Фуентеовехуна Лопеа де Веге", Наслеђе, часопис за књижевност, језик, уметност и културу, година V, број 9, стр. 95118.

- Lešić, Zdenko (2006) „Feministička teorija i kritika”, u: Zdenko Lešić et al., Suvremena tumačenja književnosti i književnokritičko naslijeđe XX stoljeća. Sarajevo: Sarajevo Publishing, str. 420-455. 
- López Estrada, Francisco (1996) "Introducción crítica", in: Lope de Vega, Fuente Ovejuna, edición, introducción y notas de Francisco López Estrada, $7^{a}$ edición renovada. Madrid: Editorial Castalia, pp. 5-49.

- Matas, Julio (1981) "El honor en Fuenteovejuna y la tragedia del comendador", in: Manuel Criado de Val (Dir.), Lope de Vega y los orígenes del teatro español (Actas del I Congreso Internacional sobre Lope de Vega). Madrid: EDI-6, pp. 385-390.

- MacGrady, Donald (2001) "Noticia de Lope de Vega Carpio y de Fuente Ovejuna", in: Lope de Vega, Fuente Ovejuna, edición de Donald MacGrady, Barcelona: Editorial Crítica, pp. 123-170.

- Parker Aronson, Stacey L. (2015) "They Said, She Said: Making the Case for Rape in Fuenteovejuna", Bulletin of the Comediantes, Vol. 67, No. 2, pp. 33-47, dostupno na: https://digitalcommons.morris.umn.edu/cgi/ viewcontent.cgi?article $=1003 \&$ context $=$ span_facpubs [Poslednji put pristupljeno 21.02.2021].

- Penas Ibáñez, Azucena (2004) Félix Lope de Vega, Madrid: Ediciones Eneida.

- Rodríguez Cacho, Lina (2009) Manual de Historia de la Literatura Española, Vol. 1 (Siglos XIII al XVII). Madrid: Editorial Castalia.

- Rodríguez-San Pedro Bezares, Luis E. \& José Luis Sánchez Lora (2000) Los siglos XVI-XVII (Cultura y vida cotidiana). Madrid: Editorial Síntesis.

- Ruiz Ramón, Francisco (1991) "Introducción a una lectura de Fuenteovejuna", in: Lope de Vega, Fuenteovejuna, edición, introducción y notas de Francisco Ruiz Ramón, Salamanca: Publicaciones del Colegio de España, pp. 9-85.

- Ruiz Ramón, Francisco (2000) Historia del teatro español (Desde sus orígenes hasta 1900), 10a edición. Madrid: Ediciones Cátedra.

- Sánchez Dueñas, Blas (2008) De imágenes e imaginarios: la percepción femenina en el Siglo de Oro. Málaga: Servicio de Publicaciones de la Universidad de Málaga.

- Selden, Raman, Peter Widdowson, Peter Brooker (1997) A Reader's Guide to Contemporary Literary Theory, $4^{\text {th }}$ edition. London: Prentice Hall.

- Stojanović, Jasna (2009) Špansko pozorište baroka. Beograd: Filološki fakultet. 
Vladimir Karanović

Faculty of Philology, University of Belgrade

\title{
VIOLENCE AGAINST WOMEN AND THE DISCOURSE ON THE FEMALE BODY IN THE DRAMA FUENTE OVEJUNA BY LOPE DE VEGA
}

\begin{abstract}
Considering general theoretical assumptions of feminist criticism, especially that related to the discourse on female body and the context of specific patterns of socially acceptable behaviour (namely, honour and chastity) in baroque Spain, this paper discusses the marginalized image of women and the mechanisms of perception of the female body in the drama Fuente Ovejuna by Lope de Vega (1562-1635). The main goals of this research are: concretization of the marginalized position of women in the rigid Spanish society of the "Golden age"; pointing to the process in which the body, especially the female body, appears in the drama of the Spanish Baroque writer not only as an object of desire, but also as a passive, objectified guardian of morals and family honor; determining the function of violence against women and specific (non)subversive discourse on the female body. These problem fields contribute to a concrete analysis of the overall (anti)feminist ideology of Lope de Vega, in whose dramatic oeuvre the alleged revolutionary and libertarian potential was often emphasized, while the tribute to the era and spirit of the time in which the writer lived and created were neglected.
\end{abstract}

Key words

Lope de Vega, Fuente Ovejuna, Spanish Baroque theater, violence against women, feminist criticism 